\title{
Screening and potent applicability analysis of commonly used pesticides against desert locust: an integrative entomo-informatics approach
}

\author{
Anik Banik ${ }^{1}$, Md. Fuad Mondal' ${ }^{2}$, Md. Mostafigur Rahman Khan ${ }^{1}$, Sheikh Rashel Ahmed ${ }^{1,3}$, Md. \\ Mehedi Hasan ${ }^{2 *}$ \\ ${ }^{1}$ Faculty of Biotechnology and Genetic Engineering, Sylhet Agricultural University, Sylhet- \\ 3100, Bangladesh \\ ${ }^{2}$ Department of Entomology, Sylhet Agricultural University, Sylhet-3100, Bangladesh \\ ${ }^{3}$ Department of Plant and Environmental Biotechnology, Sylhet Agricultural University, Sylhet- \\ 3100, Bangladesh
}

*Corresponding author (Md. Mehedi Hasan, Email: mehedih.sau@gmail.com, +8801710798263)

\begin{abstract}
The locust problem is a global threat for food security. Locusts can fly and migrate overseas within a zip and creating a large-scale devastation to the diversified agro-ecosystem. GIS based analysis showed the recent movement of locusts, among them Schistocerca gregaria and Locusta migratoria are predominant in Indian subcontinent and are found more notorious and devastating one. This devastation needs to be stopped to save human race from food deprivation. In our study, we screened some commonly used agricultural pesticides and strongly recommended three of them $v i z$. biphenthrin, diafenthiuron and silafluofen which might be potential to control the desert locusts based on their binding affinity towards the locust's survival proteins. Our phylogenetic analysis reveals that these three recommended pesticides might also show potency to the other locust species as well as they are also way safer than the other commercially available pesticides. These proposed pesticide's bioactive analogs from fungus and bacteria may also show efficacy as next generation controlling measures of locust as well as different kind of pests. These recommended pesticides are expected to be highly effective against locusts and needs to bring forward by the entomologists' by performing experimental field trials.
\end{abstract}




\section{Keywords}

Desert locusts, GIS mapping, pesticides, phylogenic analysis, molecular docking, microbial volatile compound, molecular dynamics

\section{Highlights}

1. GIS map unmasked the 2020 migratory pattern of locusts which now predominant towards Indian subcontinent.

2. Biphenthrin, diafenthiuron and silafluofen showed maximum binding affinity.

3. Biphenthrin and diafenthiuron were relatively safer than silafluofen.

4. Bioactive analogs from fungus and bacteria could be an alternative to control locusts.

5. Pesticides inhibition hotspots for desert locusts were unrevealed. 


\section{Introduction}

Locusts belongs to the family Acrididae, are the short-horned grasshoppers which are one of the most diverse agricultural and ecologically important pests [1,2]. There are 19 locust species reported around the world by different study [3-5]. Among them, some species viz. Locusta migratoria, Schistocerca gragaria, Locustana pardalina, Schistocerca piceifrons, Calliptamus italicus, Dociostaurus maroccanus, Nomadacris septemfasciata, Schistocerca cancellata are devastating. Moreover, L. migratoria and S. gragaria are most devastating in recent year [6,7]. The solitary locust become more abundant by changing their behavior under certain circumstances, becoming gregarious and can be serious pests of agriculture due to their ability to form dense and highly mobile swarms $[2,8]$. Gregarious locusts in one region can migrate to another region in a single night about hundreds of kilometers and plagues can spread out continents [3].

These divesting species affected more than 500 plant species including different crops, fruits and trees [2,9]. An adult desert locust can consume its own weight fresh food per day and $1 \mathrm{~km}^{2}$ size swarm desert locusts eat about 35,000 people's food per day [9]. Moreover, the species of locusts was a reason for a devastating plague in 2470 to $2220 \mathrm{BC}$ was mentioned in the Holy Book of Bible taking place in Egypt [10,11]. In addition, the migratory locust from China named Asian migratory locust showed their devastating phenomenon as plague from $200 \mathrm{BC}$, which was accelerated by droughts and flood events [12,13] Different Mediterranean and sub-Saharan country as well as drought area of Africa, Europe, middle Asia and eastern Asia were affected by locust several times [14-16]. The incidence of 1949-57, Morocco lost \$60 million and in 1958 Ethiopia lost $167,000 \mathrm{MT}$ of grain. At the end of last century, $\$ 310$ million was used globally for only locust control [6].

The current outbreak began in 2018 when Cyclone Mekunu produced heavy rains in the Rub' al Khali of the Arabian Peninsula. In spring 2019, swarms spread from these areas, and by June 2019, the locusts spread north to Iran, Pakistan, India and south to East Africa, particularly the Horn of Africa [17]. According to the Food and Agriculture Organization (FAO), the desert locust is spreading over more than 30 countries in the world and reported as most dangerous migratory pest. In this year, locusts swarm already affected large numbers in several countries, including Ethiopia, Eritrea, Yemen, Oman, Uganda, Kenya, Somalia, Iran, Saudi Arabia, India and Pakistan. Recently, 
FAO forecasted that, explosive multiplication of Locust swarms' forms disasters for large parts of Asia and Africa in this year.

Fight against locust using pesticides is a common practice in many countries of the world. In addition, fight against these notorious locust different biological control approaches are also being used $[7,18]$. The affected countries are using different group of pesticides in large scale but not yet much effective as their expectation [6]. As locust invade with a huge swarm it's very difficult to control [6]. Moreover, the migratory behavior also affects the control process. Therefore, countries are facing challenges for controlling thus pest. In such a circumstances computational approach could be better way to find effective solution for managing this notorious pest. Computational chemistry in particular, virtual screening can provide valuable insights in hit and lead effective compound discovery. Numerous software tools have been developed to meet the purpose [19]. In this study, we evaluated several commercially available pesticides to find the best fitted pesticide among them to combat the devastating notorious locust by using several computational approaches.

\section{Materials and Methods}

\subsection{GIS based mapping of Desert locust infestation areas}

The GIS based data of Desert locust infestation point and infestation area were retrieved from the "Locust Hub" and "Locust Watch" sorting according to the period of infestation and analyzed by the different analyzing tools of GIS base software (ArcGIS 10.7.1) (https://locust-hubhqfao.hub.arcgis.com/, http://www.fao.org/ag/locusts/en/info/info/index.html). The retrieved data period was June, 1985 to September, 2020.

\subsection{Retrieval of target locust proteins/protein-domains and insecticides}

The RCSB Protein Data Bank [20] was used for the retrieval of 3D structures of S. gregaria lipid binding protein (PDB ID: 2GVS) and Muscle fatty acid binding protein (PDB ID: 1FTP) along with L. migratoria fatty acid binding protein from flight muscle (PDB ID: 2FLJ) and Odorant binding protein (PDB ID: 4PT1). A total of 31 insecticide (Supplementary file 1), used against different orthoptera (e.g. grasshopper locust, cricket etc.) were extracted from PubChem database 
(https://pubchem.ncbi.nlm.nih.gov/) [21] in SDS (3D) format (Table 1). Now the OpenBabel v3.1.1 software was utilized to convert the retrieved SDF structure into PDB format for further analysis $[22,23]$.

\subsection{Phylogenic Analysis of proteins}

Phylogenetic analysis is the means by which evolutionary relationships are calculated. The sequence of a particular gene or protein can be used in molecular phylogenetic research to determine the evolutionary relationships of organisms. Our targeted two species's protein's FASTA format were retrieved from PDB [20] and for homologous protein we performed BLASTp (https://blast.ncbi.nlm.nih.gov/Blast.cgi?PAGE=Proteins) excluding the parent organism. Then the tree was constructed by the maximum-likelihood method using MEGA X software [24].

\subsection{Molecular docking of insecticides against locust proteins/protein-domains}

Molecular docking is a key tool in structural molecular biology and it proposes structural hypotheses of how the ligands inhibit the target, which is invaluable in lead optimization [25]. The binding affinity of protein-ligand complexes were ranked via this effective method [26,27]. The binding affinity of 31 insecticides with different locust proteins/protein domains was calculated using PatchDock server which implies the shape complementary principal-based algorithm and the docking was done with clustering RMSD 4.0 and other default parameters [23,28,29]. For refining the protein-ligand docked complexes, FireDock refinement tool [30] was utilized. Finally, the visualization of protein-ligand complexes was visualized by Discovery Studio v3.1 [31] and PyMOL v2.0 [32].

\subsection{Free binding energy calculation and Molecular Dynamics Stimulation}

The LARMD server (http:/chemyang.ccnu.edu.cn / ccb / server / LARMD) was used to investigate the ligand-protein interactional binding mode based on conventional molecular dynamics [33]. The binding free energy ( $\Delta G$ bind) was calculated based on binding energy ( $\Delta E$ bind), solvation entropy ( $T \Delta S$ sol) and conformational entropy ( $-T \Delta S \operatorname{conf})$ [34]. The enthalpy and the entropy were calculated by the MM/GBSA method [35] and empirical method, respectively [36,37].

$\Delta$ Gbind $=\Delta$ Ebind $-\mathrm{T} \Delta$ Ssol $-\mathrm{T} \Delta$ Sconf. 
Molecular dynamics study was performed to signify protein-ligand complex stability for strengthening our prophesy. The normal modes of proteins can be compared to essential dynamics to determine their stability with their fluctuation plot analysis [38-40]. iMODS an online server, utilizes to analyze of normal modes (NMA) in internal coordinates which comprises deformability, $\mathrm{B}$ factor and Eigen value parameters which helps to understand the collective motion of proteins [41]. Further, stimulation was performed for 4ns on LARMD server to calculate the root mean square deviation (RMSD) and radius of gyration (Rg) of ligands and Root mean square fluctuation (RMSF). All the snapshots from the trajectory with a time interval per picosecond by using the Cpptraj module in the AMBER16 program were provided [42]. RMSD, Rg, and RMSF were simultaneously analyzed through this module.

\subsection{Toxicity analysis of pesticides}

The relative toxicity of top pesticide candidates was predicted via pkCSM web server. The server pkCSM, a novel method for predicting and optimizing small-molecule toxicity properties which relies on distance-based graph signatures [43]. Notably, the data mining process utilized for bird toxicity, rat toxicity, Fish toxicity of the pesticides through literature study $[21,44,45]$.

\subsection{Prediction of structural Analogs of pesticides}

mVOC v2.0 web tools were used to identify potential small molecules against locust based on homology screening of predicted top pesticides. The server allowed ligand-based virtual screening of several libraries of small molecules to find available similar microbial volatile compound with known fungi and bacterial which are volatile emitters using several methods [46].

\section{Results}

\subsection{GIS based mapping of Desert locust infestation areas}

All the information of locust infestation showed the affected areas of Middle East, Northern Africa, Central and Southern Asia (Figure :1A). However, the recent outbreak of locust showed little bit different movement status. The new invasion area is gradually increasing in Southern Asia than the African region. The desert locust (S. gregaria and L. migratoria; most devastating in Middle East) moved to Indian subcontinent from Middle East over the Arab sea with long flight (Figure 
1B). The results showed that the Ethiopia, Eritrea, Somalia, Yemen, Oman, Saudi Arabia, Pakistan are highly infested country among the desert locust infestation recorded country in 2020 outbreak (Figure 1:C). Moreover, several states of India also affected and faced threat in different crops (grain, pulse, vegetables and economically important trees) producing state. Furthermore, the neighbor country of Mali, Nigeria, Mauritania are challenging threat for desert locust rapid invasion.

\subsection{Phylogenic Analysis of proteins}

The phylogenetic analysis revealed that our targeted proteins from S. gregaria and L. migratoria are very much closely related to other locust species. Proteins like the muscle fatty acid binding protein of S. gregaria was closely related to several locust species protein such as Halyomorpha haly, Riptortus pedestris, Nilaparvata lugens etc. The CSPsg4 lipid binding protein from S. gregaria were closely related to proteins of Ceracris kiangsu, Oedaleus infernalis, L. migratoria etc. The fatty acid binding protein and the odorant binding protein from L. migratoria showed the close relationships with the S. gregaria, H. haly, R. pedestris, N. lugens and C. kiangsu, O. infernalis, L. migratoria, C. nigricornis etc. respectively (Figure: 2). The tree was constructed using maximum likelihood method so the results shows the related protein has a probability of distribution by maximizing a likelihood function.

\subsection{Molecular docking of locust protein/protein domain against pesticides}

All of the retrieved structures of two different locust sp. (S. gregaria and L. migratoria) proteins/protein-domains (macromolecules) and pesticide (ligands) were prepared and employed for molecular docking to predict the affinity between above mentioned ligands and the macromolecules. The pesticides were ranked based on global binding energy and the results insights that top three scorers (pesticide) were similar for each of the macromolecules in terms of minimum binding energy (Supplementary File 2). In each case biphenthrin, diafenthiuron and silafluofen, showed best binding interactions with the four studied macromolecules (Figure 3 and Table 2). Moreover, silafluofen showed highest binding affinity with L. migratoria Fatty acid binding protein $(-50.41 \mathrm{kcal} / \mathrm{mol})$ (figure 4:B and Table 2$)$ and also with Fatty-acid binding protein from S. gregaria (-48.73 kcal/mol) (figure 4:D and Table 2), while diaphenthiuron has bound with L. migratoria odorant binding proteins with a binding energy of $53.85 \mathrm{kcal} / \mathrm{mol}$ (Figure 4:C and Table 2) and biphenthrin bound with lipid binding protein from $S$. 
gregaria with a binding energy of $-38.20 \mathrm{kcal} / \mathrm{mol}$. (Figure $4 \mathrm{~A}$ and Table 2 ). bendiocarb were used as a control in our study because of it's uses for controlling locust problems worldwide [47].

\subsection{Analysis of pesticide inhibition surface hotspots}

The molecular interaction between the ligands and target protein reveals the inhibition hotspots. It reveals the ligands were well fitted to the binding pockets of $2 \mathrm{GVS}$ by interacting amino acids like Tyr4, Tyr8, Ala 40 (Figure 5:A); 1FTP protein the ligand interacting amino acid residues such as Ile41, Leu77, Ile106, Ile117 etc. (Figure 5:B). The ligands attached with 4PT1 by interacting Ile54, Met55, Val76, Pro77, Tyr110, Tyr118, Val121, Val122 etc. (Figure 5:C). For 2FLJ the interacting molecule are Pro115, Tyr 20, Leu 77, Ile106 etc. (Figure 5:D). These binding sites can play a pivotal role for inhibiting the targeted proteins.

\subsection{Free binding energy calculation and Molecular Dynamics stimulation}

The free binding energy was calculated and found the pesticides had relatively good interactions with all the targeted proteins as evident from their negative binding free energies with biphenthrin and diafenthiuron having the highest binding affinity (Table 3), Notably, the 4PT1 protein with both biphenthrin and diafenthiuron showed maximum free binding energy among the studied complexes, with negative value describing the potential ease and stable interaction for the complex. For 4PT1- biphenthrin complex the MM/PBSA was calculated $-27.38 \mathrm{kcal} / \mathrm{mol}$ and in $\mathrm{MM} / \mathrm{GBSA}$ method it was $-34.76 \mathrm{kcal} / \mathrm{mol}$; 4PT1- diafenthiuron complex showed $-24.77 \mathrm{kcal} / \mathrm{mol}$ and $-34.08 \mathrm{kcal} / \mathrm{mol}$ for MM/PBSA and MM/GBSA, respectively.

The most widely used molecular dynamics is the conventional type which describe the binding mode of ligand and the variation of protein internal dynamics. The normal mode analysis can be done by evaluating the deformability status of a complex, the experimental $b$ factor and the eigen value.

The main-chain deformability which is a theoretical potential of any protein to deform at each of its residues. The results of our studied complexes revealed that all complexes had low flexibility potential and show resistance to deform (Figure 6: A-i, B-I, C-i, D-i; 7: A-i, B-i, C-i, D-i). The experimental B-factor which compares the normal mode analysis and the PDB field of the protein and predicted the corresponding uncertainty of their atomic positions showed that odorant binding protein of L. migratoria had the highest rigidity among the selected proteins and significance 
fluctuations weren't found which proved the fact of lower loops (Figure 7:C-ii, D-ii). The energy required to deform the proteins is for all complexes and among studied complexes, the fatty acid binding protein from L. migratoria flight muscle and odorant binding protein of L. migratoria, as indicated by the highest eigenvalue of $6.227777 \times 10^{-4}, 3.065329 \times 10^{-5}$ compared to muscle fatty-acid binding protein of $S$. gregaria and lipid binding protein of S. gregaria which eigen value of $9.914118 \times 10^{-5}, 8.045085 \times 10^{-5}$ respectively (Figure 6:A-vi, B-vi, C-vi, D-vi ; 7: C-vi, D-vi).

From the result, the average RMSDs of CA atoms were normally distributed around 1-3 $\AA$ (Figure 6: A-iv, B-iv, C-iv, D-iv; 7:A-iv, B-iv, C-iv) except the odorant binding protein of L. migratoria diafenthiuron complex which shows a bit fluctuation (Figure 7:D-iv). These results justified the true binding pose of the complexes. Although complexes of to muscle fatty-acid binding protein of S. gregaria - biphenthrin, fatty acid binding protein from L. migratoria flight musclediafenthiuron, lipid binding protein of $S$. gregaria- biphenthrin shows receptor-ligand equilibrium state (Figure 6: A-iv, D-iv; 7: A-iv). The Rg value range fluctuated between 13.4 to 21.4 for all complexes (Figure 6: A-v, B-v, C-v, D-v; 7: A-v, B-v, C-v, D-v). The RMSF plot of the complexes was found to align with all the target protein residues. The per residue Root Mean Square Fluctuations (RMSF) (Figure 6: A-iii, B-iii, C-iii, D-iii; 7: A-iii, B-iii, C-iii, D-iii) showed regular fluctuation pattern between 3 and $15 \AA$.

\subsection{Toxicity analysis of pesticides}

Prediction of various toxicity parameters such as AMES toxicity, minnow toxicity, fish toxicity, bird toxicity etc. were analyzed (Table 4). Estimated $\mathrm{LD}_{50}$ for biphenthrin, diafenthiuron and silafluofen were $2.776,2.432$ and $2.433 \mathrm{~mol} / \mathrm{kg}$, respectively. The fish toxicity results revealed the pLC50 for biphenthrin, diafenthiuron and silafluofen were -1.05550 .3532 and $0.6658 \mathrm{mg} / \mathrm{L}$ respectively, means the silafluofen were tends to more toxic to fish than the other two pesticides. None of the compounds showed any undesired effects such as hERG I inhibitor, skin sensitisation, but silafluofen may possess some toxic consequences to bird and also exhibits positive result in AMES toxicity test.

\subsection{Prediction of structural Analogs of pesticides}

Ligand-based virtual screening was performed to predict small compounds from living organisms from mVOC v2.0 database. These living organisms derived small compounds which may provide 
a next sophisticated step towards the next generation pest management strategies. Dioctyl benzene1,2-dicarboxylate (Pubchem CID 8346) also named dioctyl phthalate and dibutyl benzene-1,2dicarboxylate (Pubchem CID 3026) also known as dibutyl phthalate derived from two bacterial species were found analogous to Biphenthrin with prediction score 0.47 and 0.42 respectively. Moreover, results revealed the similarity of 4-ethyl-2-methoxy-6-methylphenol (Pubchem CID 183540) and 3-propylphenol (Pubchem CID 69302) derived from two fungal species with Silafluofen with high prediction score (Table 5). The findings suggest that these could be potential pest management candidates against the devastating notorious pests, thus this requires further experimental trials for validation.

\section{Discussion}

The Desert Locust continues its footsteps, becoming a major threat to food security in several country of the world. Strategies of their invasion hold a high expense for the impacted nations, also a threat for ecological balance $[6,48]$. GIS based cartography illustrated the worldwide distribution of desert locust where $S$. gregaria and L. migratoria were the major desert locust species [6,7]. The results also indicate the swarm migration extend to Indian subcontinent and middle east in recent outbreak. It might be accelerated by the favorable environmental condition viz. temperature pattern, sudden rainfall sometimes direction of wind for locust migration $[49,50]$. Recently, almost thirty country has infested by this devasting pest and also threaten to several neighbor country [17]. Several pesticides were used widely in various countries to kill or control locust like bendiocarb but it doesn't seem much more effective for controlling locusts [47,51]. Though some pesticides candidates are in the trial stages but already many of them raise controversial issues for their negative consequences towards environment and humans $[52,53]$. The world is intended to find an effective and justified controlling measures for minimizing the devastation by any possible means [54]. Several pesticides were evaluated against the proteins of desert locust using computational approaches to find out the best possible mean with higher effectivity and less possible environmental and human impact.

The computer aided inhibitor design has been contributed to accelerate the inhibitor discovery for several pest problems. By these approaches, the possibilities of potent small molecules as ligands/inhibitors can be explored [55]. Pesticides like chlorpyrifos, deltamethrin, diflubenzuron, lambda-cyhalothrin has been used as potential locust controlling agent. But these pesticides don't 
pass the expectation level. They have also a wide range of toxic complications [47,56]. The several studies showed Bendiocarb used against locust that has similar level of activity as previously mentioned locust controlling pesticides with comparatively higher level of toxicity [47,51]. We used bendiocarb as a positive control in our study for our targeted proteins.

Some commonly pesticides were screened against desert locust species proteins such as lipid binding protein (2GVS) and muscle fatty acid binding protein (1FTP) from S. gregaria along with odorant binding protein (4PT1) and flight muscle fatty acid binding protein (2FLJ) from $L$. migratoria using a molecular docking approach [57].

The lipid binding protein (2GVS) of $S$. gregaria is a chemosensory protein. Chemosensory proteins are soluble proteins found in insect's chemosensory organs which are responsible for chemical message transmission and this chemical stimulus has been referred extremely important for the survival of various insect species [58]. The muscle fatty acid binding protein (1FTP) of $S$. gregaria has a vital role in fatty acid transport and metabolism [59]. The odorant binding protein (4PT1) of L. migratoria is crucial to find their plant hosts through which they find feed for survival utilizing their olfactory system [60] and the flight muscle fatty acid binding protein (2FLJ) of $L$. migratoria plays a vital role in their wing movement by transportation of fatty acid [61].

Remarkably, three pesticides i.e. biphenthrin, diaphenthiuron and silaflufen scored best for each four macromolecules and bound with minimum global binding energy (Table 2) and Supplementary File 2). Silafluofen showed highest binding affinity with both L. migratoria fatty acid binding protein $(-50.41 \mathrm{kcal} / \mathrm{mol})$ (Figure 4B Table 2$)$ and also with fatty-acid binding protein from $S$. gregaria (-48.73 kcal/mol) (Figure 4D Table 2 ), while diaphenthiuron has bound with $L$. migratoria odorant binding proteins with a binding energy of $-53.85 \mathrm{kcal} / \mathrm{mol}$ (Figure 4C Table 2) and biphenthrin bound with lipid binding protein from $S$. gregaria with a binding energy of -38.20 $\mathrm{kcal} / \mathrm{mol}$. (Figure $4 \mathrm{~A}$ Table 2 ). The scores of top candidates were higher than bendiocarb, a positive control used in the present study (Table 2). The silaflufen and biphenthrin generally acts in sodium channel modulators of pest and make a significant impact on their nerve, the other one which is diafenthiuron targets mitochondrial ATP synthase and seriously effects energy metabolism (Table 1) [62].

The molecular interaction between the ligands and target protein reveals the inhibition hotspots. It reveals the ligands were well fitted to the binding pockets of targeted proteins by interacting 
several amino acids like Tyr4, Tyr8, Ile119,Ile11, Tyr50, Leu51, Ile54, Met55 etc. by several kinds of bonding and most of bindings are relatively in hydrophobic environment, which may help to stabilize its conformation and these ligand-protein hydrophobic interactions can play a crucial role because these may help in stabilizing the complex and improved the efficacy of the inhibitor [63]. Molecular dynamics stimulation of biphenthrin and diafenthiuron was studied with all four protein complexes. The free binding energy calculation shows negative result for all proteins means the strong binding affinity and the normal mode analysis uncover that the complexes were stable with the ligand. The all docked complexes B factor and deformability analysis showed less hinges means the rigidity and stability of the complexes. The comparatively higher eigen value for locust flight muscle protein with pesticides complexes confirms its strong stiffness than others. The odorant binding protein of L. migratoria - diafenthiuron complex which shows a bit fluctuation (Figure 7:D-iv). The lower the RMSD distribution in $\AA$, higher possibility of complex true pose. The founded results justified the true binding pose of the complexes. Notable, complexes of to muscle fatty-acid binding protein of $S$. gregaria - biphenthrin, fatty acid binding protein from $L$. migratoria flight muscle-diafenthiuron, lipid binding protein of S. gregaria- biphenthrin shows receptor-ligand equilibrium state ((Figure 6: A-iv,D-iv; 7: A-iv)). The Rg value range fluctuated between 13.4 to 21.4 for all complexes ((Figure 6: A-v, B-v, C-v, D-v; 7: A-v, B-v, C-v, D-v). The per residue Root Mean Square Fluctuations (RMSF) (Figure 6: A-iii, B-iii, C-iii, D-iii; 7: A-iii, Biii,C-iii, D-iii)) showed regular fluctuation pattern. These analysis insights negligible chance of deformability as hinges are in the chain was not significant and strongly validate our prediction. According to our encouraging results, the toxicity pattern among these top three candidates reveals that biphenthrin and diafenthiuron were relatively safer than silaflufen in terms of bird, fish, human and other toxicity parameter (Table 4). The phylogenetic analysis of our targeted 4 protein from 2 different species shows close relationship with other pest species precisely to the various locusts such as $H$. haly, $R$. pedestris, $N$. lugens, C. kiangsu, O. infernalis, $R$. pedestris, $C$. nigricornis. We suggest, our top screened three pesticides may also prove their effectiveness against these pest species also. The structural similarity search of our top screened three pesticides found analogs to the several microbial volatile compounds. Dioctyl benzene-1,2-dicarboxylate (Pubchem CID 8346) and dibutyl benzene-1,2-dicarboxylate (Pubchem CID 3026) derived from two bacterial species were found analogous to biphenthrin with high prediction score 0.47 and 0.42 respectively (Table 5). Moreover, results revealed the similarity of 4-ethyl-2-methoxy-6-methylphenol 
(Pubchem CID 183540) and 3-propylphenol (Pubchem CID 69302) derived from two fungal species with silafluofen with high prediction score (Table 5). The findings suggested that these could be potential pest management candidates also against the devastating notorious locust, as they are derived from living microorganisms. They have the potential to break down the ice of the controversial argument with use of pesticides which requires further experimental field trials for validation.

\section{Conclusion}

The result suggests that biphenthrin, diafenthiuron and silaflufen could be option to combat desert locust. Furthermore, two biological derived structural analogs from mVOC i.e. dioctyl phthalate and dibutyl phthalate may be effective and show inhibitory properties against the desert locust essential proteins. Due to the encouraging results, we highly recommend further in the field trials for the experimental validation of our findings.

\section{Acknowledgment}

We acknowledge Department of Entomology, Sylhet Agricultural University and Department of Plant and Environmental Biotechnology, Sylhet Agricultural University for their technical support.

\section{Conflict of interest}

The authors declare no conflict of interest.

\section{Funding information}

This study has no funding from governmental, commercial or any kind of institutional authorities.

\section{References}

1. J. P. Dempster, The population dynamics of grasshoppers and locusts, Biological Reviews. 38(4) (1963) 490-529. 
2. S. Ingrisch, and D. C. F. Rentz, Orthoptera: Grasshoppers, Locusts, Katydids, Crickets, In Encyclopedia of Insects. (2009) 732-74. https://doi.org/10.1016/B978-0-12-3741448.00196-X

3. M. Le Gall, R. Overson, and A. J. Cease, A global review on locusts (Orthoptera: Acrididae) and their interactions with livestock grazing practices, Frontiers in Ecology and Evolution. 7 (2019) 263.

4. S. Ramesh, Biological and environmental hazards, risks, and disasters. Biological and environmental hazards, risks, and disasters. (2015) pp.492.

5. A. Vijayalakshmia, and M. Meenaa, Crop destructor-locust-a critical review, Journal of Xidian University. 14, (7) (2020) 1798-1804. DOI: 10.37896/jxu14.7/206

6. Y.T. Belayneh, Acridid pest management in the developing world: a challenge to the rural population, a dilemma to the international community, Journal of Orthoptera Research. 14(2) (2005) 187-195. https://doi.org/10.1665/1082-6467(2005)14[187:APMITD]2.0.CO;2.

7. W. Peng, N. L. Ma, D. Zhang, Q. Zhou, X. Yue, S. C. Khoo.. and Y. Wang, A review of historical and recent locust outbreaks: Links to global warming, food security and mitigation strategies, Environmental Research. (2020) 110046.

8. J. S. Kennedy, Phase transformation in locust biology, Biological Reviews. 31(3) (1956). 349370.

9. K. Cressman, Desert locust, Biological and Environmental Hazards, Risks, and Disasters. (2016) 87-105.

10. J. Colvin, S. Krall, R. Peveling, and D. Ba Diallo, New strategies in locust control. (1997).

11. D. E. Moore, " Too Much to Grasp": Exodus 3: 13-15 and the Reality of God, Journal of the Evangelical Theological Society. 59(4) (2016) 823.

12. L. C. Stige, K. S. Chan, Z. Zhang, D. Frank, and N. C. Stenseth, Thousand-year-long Chinese time series reveals climatic forcing of decadal locust dynamics, Proceedings of the National Academy of Sciences. 104(41) (2007) 16188-16193.

13. H. Tian, L. C. Stige, B. Cazelles, K. L. Kausrud, R. Svarverud, N. C. Stenseth, and Z. Zhang, Reconstruction of a 1,910-y-long locust series reveals consistent associations with climate fluctuations in China, Proceedings of the National Academy of Sciences. 108(35) (2011) 14521-14526. 
14. D. E. Pedgley, D. R. Reynolds, and G. M. Tatchell, Long-range insect migration in relation to climate and weather: Africa and Europe. Insect migration: tracking resources through space and time. (1995) 3-29.

15. A. V. Latchininsky, Moroccan locust Dociostaurus maroccanus (Thunberg, 1815): a faunistic rarity or an important economic pest?, Journal of Insect Conservation. 2(3-4) (1998) 167-178.

16. D. Gómez, P. Salvador, J. Sanz, and J. L. Casanova, Modelling desert locust presences using 32-year soil moisture data on a large-scale, Ecological Indicators. 117 (2020) 106655.

17. FAO, FAO Locust Watch, Food and Agriculture Organization of the United Nations, Rome, Italy. (2020). http://www.fao.org/ag/locusts Accessed on 07 August 2020.

18. P. W. Walker, P. G. Story, and G. C. Hose, Comparative effects of pesticides, fenitrothion and fipronil, applied as ultra-low volume formulations for locust control, on non-target invertebrate assemblages in Mitchell grass plains of south-west Queensland, Australia, Crop Protection. 89 (2016) 38-46. DOI: 10.1016/j.cropro.2016.06.020

19. G. Schneider, Virtual screening: an endless staircase?, Nat Rev Drug Discov. 9 (2010) 273 276. https://doi.org/10.1038/nrd3139

20. P.W. Rose, A. Prlić, A. Altunkaya, C. Bi, A.R. Bradley, C.H. Christie, et al., The RCSB protein data bank: Integrative view of protein, gene and 3D structural information, Nucleic Acids Res. 45 (2017) D271-81.

21. S. Kim, P.A. Thiessen, E.E. Bolton, J. Chen, G. Fu, A. Gindulyte, L. Han, J. He, S. He, B.A. Shoemaker, J. Wang, PubChem substance and compound databases, Nucleic acids research. 4;44(D1) (2016) D1202-13.

22. N.M. O'Boyle, M. Banck, C.A. James, C. Morley, T. Vandermeersch, G.R. Hutchison, Open Babel: An open chemical toolbox, Journal of cheminformatics. 3(1) (2011) 33.

23. Azim, K.F., Ahmed, S.R., Banik, A., Khan, M.M.R., Deb, A. and Somana, S.R., 2020. Screening and druggability analysis of some plant metabolites against SARS-CoV-2: An integrative computational approach. Informatics in Medicine Unlocked, p.100367.

24. S. Kumar, G. Stecher, M. Li, C. Knyaz, and K. Tamura, MEGA X: molecular evolutionary genetics analysis across computing platforms, Molecular biology and evolution. 35(6) (2018) 1547-1549.

25. G.M. Morris, and M. Lim-Wilby, Molecular docking. In Molecular modeling of proteins. (2008) 365-382. https://doi.org/10.1007/978-1-59745-177-2_19 
26. S.Y. Huang, X. Zou, Advances and challenges in protein-ligand docking, Int. J. Mol. Sci. 11 (2010) 3016-3034. DOI: 10.3390/ijms11083016

27. F. López-Vallejo, T. Caulfield, K. Martínez-Mayorga, M.A. Giulianotti, R.A. Houghten, A. Nefzi, J.L. Medina-Franco, Integrating virtual screening and combinatorial chemistry for accelerated drug discovery, Comb. Chem. High Throughput Screen. 14 (2011) 475-487.

28. D. Schneidman-Duhovny, Y. Inbar, R. Nussinov, H.J. Wolfson, PatchDock and SymmDock: servers for rigid and symmetric docking, Nucleic acids research. 1;33(suppl_2) (2005) W3637.

29. Rahman, M.R., Banik, A., Chowdhury, I.M., Sajib, E. and Sarkar, S., 2020. Virtual Screening of Some Antivirals That Can Be Repurposed As Potential Effective Drugs against SARS-CoV2 .

30. E. Mashiach, D. Schneidman-Duhovny, N. Andrusier, R. Nussinov, H.J. Wolfson, FireDock: a web server for fast interaction refinement in molecular docking, Nucleic acids research. 19;36(suppl_2) (2008) W229-32.

31. Q. Wang, J. He, D. Wu, J. Wang, J. Yan, H. Li, Interaction of $\alpha$-cyperone with human serum albumin: Determination of the binding site by using Discovery Studio and via spectroscopic methods, Journal of Luminescence. 1(164) (2015) 81-5. DOI: 10.1016/j.jlumin.2015.03.025

32. W.L. DeLano, Pymol: An open-source molecular graphics tool, CCP4 Newsletter on protein crystallography. 40(1) (2002) 82-92.

33. J. F. Yang, F. Wang, Y. Z. Chen, G. F. Hao, and G. F. Yang, LARMD: Integration of bioinformatic resources to profile ligand-driven protein dynamics with a case on the activation of estrogen receptor, Brief Bioinformatics. (2019) 1-13. https://doi.org/10.1093/bib/bbz141

34. K. Raha, and K. M. Merz, Large-scale validation of a quantum mechanics based scoring function: Predicting the binding affinity and the binding mode of a diverse set of protein-ligand complexes, Journal of Medicinal Chemistry. 48 (14) (2005) 4558-4575. https://doi.org/10.1021/jm048973n

35. T. Hou, J. Wang, Y. Li, \& W. Wang, Assessing the performance of the MM/PBSA and MM/GBSA methods. 1. The accuracy of binding free energy calculations based on molecular dynamics simulations, Journal of Chemical Information and Modeling. 51 (1) (2011) 69-82.

36. G. F. Hao, X.L. Zhu, F.Q. Ji, L. Zhang, G.F. Yang, and C.G. Zhan, Understanding the mechanism of drug resistance due to a codon deletion in protoporphyrinogen oxidase through 
computational modeling, The Journal of Physical Chemistry B. 113 (14) (2009). 4865-4875. https://doi.org/10.1021/jp807442n

37. Y. Pan, D. Gao, \& C.G. Zhan, Modeling the catalysis of anti-cocaine catalytic antibody: Competing reaction pathways and free energy barriers, Journal of the American Chemical Society. 130 (15) (2008) 5140-5149. https://doi.org/10.1021/ja077972s

38. D.M. Van Aalten, B.L. De Groot, J.B. Findlay, H.J. Berendsen, and A. Amadei, A comparison of techniques for calculating protein essential dynamics, Journal of Computational Chemistry. 18(2) (1997) 169-181. https://doi.org/10.1002/(SICI)1096-987X(19970130)18:2<169::AID$\mathrm{JCC} 3>3.0 . \mathrm{CO} ; 2-\mathrm{T}$

39. D.M. Van Aalten, B.L. De Groot, J.B. Findlay, H.J. Berendsen, and A. Amadei, A comparison of techniques for calculating protein essential dynamics, Journal of Computational Chemistry. 18(2) (1997) 169-181. https://doi.org/10.1002/(SICI)1096-987X(19970130)18:2<169::AID$\mathrm{JCC} 3>3.0 . \mathrm{CO} ; 2-\mathrm{T}$

40. K. Wüthrich, G. Wagner, R. Richarz, and W. Braun, Correlations between internal mobility and stability of globular proteins, Biophysical journal. 32(1) (1980) 549-560.

41. J.R. López-Blanco, J.I. Aliaga, E.S. Quintana-Ortí, and P. Chacón, iMODS: internal coordinates normal mode analysis server, Nucleic acids research. 42(W1) (2014) W271-W276.

42. D. R. Roe, and T. E. Cheatham, III. PTRAJ and CPPTRAJ: Software for processing and analysis of molecular dynamics trajectory data, Journal of Chemical Theory and Computation. 9 (7) (2013) 3084-3095. https://doi.org/10.1021/ct400341p

43. D.E. Pires, T.L. Blundell, and D.B. Ascher, pkCSM: predicting small-molecule pharmacokinetic and toxicity properties using graph-based signatures, Journal of medicinal chemistry. 58(9) (2015) 4066-4072.

44. H. Zhu, T.M. Martin, L. Ye, A. Sedykh, D.M. Young and A. Tropsha, Quantitative structure activity relationship modeling of rat acute toxicity by oral exposure. Chem. Res. Toxicol. 22(12) (2009) 1913-1921.

45. G. Wang, Y. Li, X. Liu, and Y. Wang, Understanding the Aquatic Toxicity of Pesticide: Structure-Activity Relationship and Molecular Descriptors to Distinguish the Ratings of Toxicity, QSAR Comb. Sci. 28 (2009)1418-1431. doi:10.1002/qsar.200960050 
46. M.C. Lemfack, B.O. Gohlke, S.M.T. Toguem, S. Preissner, B. Piechulla, and R. Preissner, mVOC 2.0: a database of microbial volatiles, Nucleic acids research. 46(D1) (2018) D1261D1265.

47. C.J. Lomer, R.P. Bateman, D. Dent, H. De Groote, O.K. Douro-Kpindou, C. Kooyman, J. Langewald, Z. Ouambama, R. Peveling, and M. Thomas, Development of strategies for the incorporation of biological pesticides into the integrated management of locusts and grasshoppers, Agricultural and Forest Entomology. 1(1) (1999) 71-88.

48. M. Lecoq, Desert locust threat to agricultural development and food security and FAO/international role in its control, Arab Society for Plant Protection. 21 (2003) 188-193.

49. D. R. Reynolds, W. J. Chapman, and V. A. Drake, Riders on the wind: the aeroecology of insect migrants, Aeroecology. Springer, Cham. (2017) 145-178.

50. J. S. Kennedy, The migration of the desert locust (Schistocerca gregaria Forsk.). I. The behaviour of swarms. II. A theory of long-range migrations. Philosophical Transactions of the Royal Society of London. Series B, Biological Sciences. (1951) 163-290.

51. G. Matthews, Tackling locusts and the FAO procurement of insecticides, International Pest Control. 58.1 (2016) 24.

52. W. R. Reeves, M. K. McGuire, M. Stokes, and J. L. Vicini, Assessing the safety of pesticides in food: How current regulations protect human health, Advances in Nutrition. 10(1) (2019) $80-88$.

53. M. Sudo, T. Yamanaka, and S. I. Miyai, Quantifying pesticide efficacy from multiple field trials, Population Ecology. 61(4) (2019) 450-456. https://doi.org/10.1002/1438-390X.12019

54. D.M. Bajiou, Development of a system for detection, control and prevention of locust pests using UAV platforms, BS thesis. Universitat Politècnica de Catalunya. (2018) 7-9

55. G.J. Correy, D. Zaidman, A. Harmelin, S. Carvalho, P.D. Mabbitt, V. Calaora, P.J. James, A.C. Kotze, C.J. Jackson, and N. London, Overcoming insecticide resistance through computational inhibitor design, Proceedings of the National Academy of Sciences. 116(42) (2019) 2101221021.

56. J. Stanley, G. Preetha, and Stanley, Pesticide toxicity to non-target organisms. Berlin, Germany, Springer. (2016) 1-98.

57. M.W. Chang, C. Ayeni, S. Breuer, and B.E. Torbett, Virtual screening for HIV protease inhibitors: a comparison of AutoDock 4 and Vina, PloS one. 5(8) (2010) 11955. 
58. S. Tomaselli, O. Crescenzi, D. Sanfelice, E. Ab, R. Wechselberger, S. Angeli, A. Scaloni, R. Boelens, T. Tancredi, P. Pelosi, and D. Picone, Solution structure of a chemosensory protein from the desert locust Schistocerca gregaria, Biochemistry. 45(35) (2006) 10606-10613.

59. N.H. Haunerland, B.L. Jacobson, G. Wesenberg, I. Rayment, and H.M. Holden, Threedimensional structure of the muscle fatty-acid-binding protein isolated from the desert locust Schistocerca gregaria, Biochemistry. 33(41) (1994) 12378-12385. DOI: $10.2210 / \mathrm{pdb} 1 \mathrm{FTP} / \mathrm{pdb}$

60. J. Zheng, J. Li, L. Han, Y. Wang, W. Wu, X. Qi, Y. Tao, L. Zhang, Z. Zhang, and Z. Chen, Crystal structure of the Locusta migratoria odorant binding protein, Biochemical and biophysical research communications. 456(3) (2015) 737-742.

61. L.I. Gilbert, K. Iatrou, and S.S. Gill, Comprehensive molecular insect science, Elsevier. (2005) $1-77$.

62. IRAC, Mode of Action Classification Scheme, Insecticide Resistance Action Committee (IRAC). Version 9.4 (2020). <http://www.iraconline.org>

63. R. Patil, S. Das, A. Stanley, L. Yadav, A. Sudhakar, and A.K. Varma, Optimized hydrophobic interactions and hydrogen bonding at the target-ligand interface leads the pathways of drugdesigning, PloS one. 5(8) (2010) 12029. 
Table 1: Group name, Agrochemical category, Mode of action and Impact Area of available commercial insecticides (IRAC, 2020)

\begin{tabular}{|c|c|c|c|c|c|}
\hline $\begin{array}{c}\text { Insecticides } \\
\text { Name }\end{array}$ & $\begin{array}{l}\text { PubChem } \\
\text { ID }\end{array}$ & Group Name & $\begin{array}{l}\text { Agrochemical } \\
\text { Category }\end{array}$ & $\begin{array}{c}\text { Mode of } \\
\text { Mechanism }\end{array}$ & $\begin{array}{c}\text { Impact } \\
\text { Area }\end{array}$ \\
\hline Aldicarb & 9570071 & Carbamates & $\begin{array}{l}\text { Nematicides, } \\
\text { Insecticides, } \\
\text { Acaricides }\end{array}$ & $\begin{array}{l}\text { Acetylcholinesterase } \\
\text { (AChE) inhibitors }\end{array}$ & Nerve \\
\hline Aldrin & 12310947 & Organochlorines & Insecticides & $\begin{array}{l}\text { GABA-gated } \\
\text { chloride channel } \\
\text { blockers }\end{array}$ & Nerve \\
\hline Allethrin & 11442 & Pyrethroids & Insecticides & $\begin{array}{l}\text { Sodium channel } \\
\text { modulators }\end{array}$ & Nerve \\
\hline Azamethiphos & 71482 & Organophosphates & Insecticides & $\begin{array}{l}\text { Acetylcholinesterase } \\
\text { (AChE) inhibitors }\end{array}$ & Nerve \\
\hline Biphenthrin & 6442842 & Pyrethroids & $\begin{array}{l}\text { Insecticides, } \\
\text { Acaricides }\end{array}$ & $\begin{array}{l}\text { Sodium channel } \\
\text { modulators }\end{array}$ & Nerve \\
\hline Carbaryl & 6129 & Carbamates & $\begin{array}{l}\text { Insecticides, } \\
\text { Plant growth } \\
\text { regulators }\end{array}$ & $\begin{array}{l}\text { Acetylcholinesterase } \\
\text { (AChE) inhibitors }\end{array}$ & Nerve \\
\hline Carbendazim & 25429 & Carbamates & $\begin{array}{l}\text { Alkaline } \\
\text { solution, } \\
\text { Insecticide }\end{array}$ & $\begin{array}{l}\text { Acetylcholinesterase } \\
\text { (AChE) inhibitors }\end{array}$ & Nerve \\
\hline Carbofuran & 2566 & Carbamates & $\begin{array}{l}\text { Nematicides, } \\
\text { Transformation } \\
\text { products, } \\
\text { Acaricides, } \\
\text { Insecticides }\end{array}$ & $\begin{array}{l}\text { Acetylcholinesterase } \\
\text { (AChE) inhibitors }\end{array}$ & Nerve \\
\hline Chloropyriphos & 2730 & Organophosphates & $\begin{array}{l}\text { Insecticides, } \\
\text { Acaricides }\end{array}$ & $\begin{array}{l}\text { Acetylcholinesterase } \\
\text { (AChE) inhibitors }\end{array}$ & Nerve \\
\hline Cyfluthrin & 104926 & Pyrethroids & $\begin{array}{l}\text { Insecticides, } \\
\text { Acaricides }\end{array}$ & $\begin{array}{l}\text { Sodium channel } \\
\text { modulators }\end{array}$ & Nerve \\
\hline Cypermethrin & 2912 & Pyrethroids & $\begin{array}{l}\text { Insecticides, } \\
\text { Acaricides }\end{array}$ & $\begin{array}{l}\text { Sodium channel } \\
\text { modulators }\end{array}$ & Nerve \\
\hline Diafenthiuron & 3034380 & Organosulfur & $\begin{array}{l}\text { Miticides, } \\
\text { Acaricides, } \\
\text { Insecticides }\end{array}$ & $\begin{array}{l}\text { Inhibitors of } \\
\text { mitochondrial } \\
\text { ATP synthase }\end{array}$ & $\begin{array}{l}\text { Energy } \\
\text { metabolism }\end{array}$ \\
\hline Diazinon & 3017 & Organophosphates & $\begin{array}{l}\text { Repellents, } \\
\text { Veterinary } \\
\text { substances, } \\
\text { Acaricides, } \\
\text { Insecticides }\end{array}$ & $\begin{array}{l}\text { Acetylcholinesterase } \\
\text { (AChE) inhibitors }\end{array}$ & Nerve \\
\hline Dichlorvos & 3039 & Organophosphates & $\begin{array}{l}\text { Transformation } \\
\text { products, } \\
\text { Acaricides, } \\
\text { Insecticides }\end{array}$ & $\begin{array}{l}\text { Acetylcholinesterase } \\
\text { (AChE) inhibitors }\end{array}$ & Nerve \\
\hline
\end{tabular}




\begin{tabular}{|c|c|c|c|c|c|}
\hline Dieldrin & 969491 & Organochlorines & Insecticide & $\begin{array}{l}\text { GABA-gated } \\
\text { chloride channel } \\
\text { blockers }\end{array}$ & Nerve \\
\hline Dimethoate & 3082 & Organophosphates & $\begin{array}{l}\text { Transformation } \\
\text { products, } \\
\text { Acaricides, } \\
\text { Insecticides }\end{array}$ & $\begin{array}{l}\text { Acetylcholinesterase } \\
\text { (AChE) inhibitors }\end{array}$ & Nerve \\
\hline Dinotefuran & 197701 & Neonicotinoids & Insecticides & $\begin{array}{l}\text { Nicotinic } \\
\text { acetylcholine } \\
\text { receptor (nAChR) } \\
\text { competitive } \\
\text { modulators } \\
\end{array}$ & Nerve \\
\hline Endrin & 12358480 & Organochlorines & $\begin{array}{l}\text { Insecticide, } \\
\text { rodenticides }\end{array}$ & $\begin{array}{l}\text { GABA-gated } \\
\text { chloride channel } \\
\text { blockers }\end{array}$ & Nerve \\
\hline Ethienocarb & 73555894 & Carbamates & Insecticides & $\begin{array}{l}\text { Acetylcholinesterase } \\
\text { (AChE) inhibitors }\end{array}$ & Nerve \\
\hline Etofenprox & 71245 & Pyrethroids & Insecticides & $\begin{array}{l}\text { Sodium channel } \\
\text { modulators }\end{array}$ & Nerve \\
\hline Fenitrothion & 31200 & Organophosphates & $\begin{array}{l}\text { Insecticides, } \\
\text { Acaricides }\end{array}$ & $\begin{array}{l}\text { Acetylcholinesterase } \\
(\mathrm{AChE}) \text { inhibitors }\end{array}$ & Nerve \\
\hline Fenobucarb & 19588 & Carbamates & Insecticides & $\begin{array}{l}\text { Acetylcholinesterase } \\
\text { (AChE) inhibitors }\end{array}$ & Nerve \\
\hline Fipronil & 3352 & Phenylpyrazoles & Insecticides & $\begin{array}{l}\text { GABA-gated } \\
\text { chloride channel } \\
\text { blockers }\end{array}$ & Nerve \\
\hline Heptachlor & 3589 & Organochlorines & Insecticides & $\begin{array}{l}\text { GABA-gated } \\
\text { chloride channel } \\
\text { blockers }\end{array}$ & Nerve \\
\hline Malathion & 4004 & Organophosphates & $\begin{array}{l}\text { Insecticides, } \\
\text { Acaricides }\end{array}$ & $\begin{array}{l}\text { Acetylcholinesterase } \\
\text { (AChE) inhibitors }\end{array}$ & Nerve \\
\hline Methomyl & 5353758 & Carbamates & Insecticides & $\begin{array}{l}\text { Acetylcholinesterase } \\
\text { (AChE) inhibitors }\end{array}$ & Nerve \\
\hline $\begin{array}{l}\text { Methyl } \\
\text { parathion }\end{array}$ & 4130 & Organophosphates & $\begin{array}{l}\text { Insecticides, } \\
\text { Repellants }\end{array}$ & $\begin{array}{l}\text { Acetylcholinesterase } \\
\text { (AChE) inhibitors }\end{array}$ & Nerve \\
\hline Oxamyl & 9595287 & Carbamates & $\begin{array}{l}\text { Insecticides, } \\
\text { Nematicides }\end{array}$ & $\begin{array}{l}\text { Acetylcholinesterase } \\
\text { (AChE) inhibitors }\end{array}$ & Nerve \\
\hline Parathion & 991 & Organophosphates & $\begin{array}{l}\text { Insecticides, } \\
\text { Acaricides }\end{array}$ & $\begin{array}{l}\text { Acetylcholinesterase } \\
\text { (AChE) inhibitors }\end{array}$ & Nerve \\
\hline Phosmet & 12901 & Organophosphates & Insecticides & $\begin{array}{l}\text { Acetylcholinesterase } \\
\text { (AChE) inhibitors }\end{array}$ & Nerve \\
\hline Silafluofen & 92430 & Pyrethroids & Insecticides & $\begin{array}{l}\text { Sodium channel } \\
\text { modulators }\end{array}$ & Nerve \\
\hline
\end{tabular}


Table 2: Analysis of Global binding energy and interaction sites of the screened top three pesticides

\begin{tabular}{|c|c|c|c|c|c|c|}
\hline $\begin{array}{l}\text { Protein } \\
\text { Name }\end{array}$ & $\begin{array}{l}\text { Pesticides } \\
\text { Name }\end{array}$ & $\begin{array}{l}\text { Global } \\
\text { Energy }\end{array}$ & Score & Area & $\mathrm{ACE}$ & Ligand binding residues \\
\hline \multirow[t]{4}{*}{ 2GVS } & $\begin{array}{l}\text { Control } \\
\text { (Bendiocarb) }\end{array}$ & -25.4 & 3110 & 368.2 & -4.28 & Leu13, Asp14, Lys70 \\
\hline & Biphenthrin & -38.20 & 5278 & 681.3 & -6.87 & $\begin{array}{l}\text { Glu2, Lys3, Tyr4, Thr5, Thr6, Tyr8, } \\
\text { Asp41 }\end{array}$ \\
\hline & Diafenthiuron & -33.99 & 4502 & 647.9 & -8.61 & $\begin{array}{l}\text { Glu2, Lys3, Tyr4, Tyr8, Asp42, } \\
\text { Glu44, Asn61, Lys63 }\end{array}$ \\
\hline & Silafluofen & -30.06 & 4798 & 617.6 & -7.43 & $\begin{array}{l}\text { Lys3, Tyr4, Thr6, Tyr8, Ala40, } \\
\text { Asp41, Glu44 }\end{array}$ \\
\hline \multirow[t]{4}{*}{ 1FTP } & $\begin{array}{l}\text { Control } \\
\text { (Bendiocarb) }\end{array}$ & -29.32 & 3710 & 428.7 & -7.44 & $\begin{array}{l}\text { Lys10, Val40, Lys56, Ala58, } \\
\text { Glu109, Val116, Gln133 }\end{array}$ \\
\hline & Biphenthrin & -42.46 & 5718 & 686.7 & -7.59 & $\begin{array}{l}\text { Pro39, Ile41, Thr57, Lys60, Glu74, } \\
\text { Leu77, His96, Gln98, Ile106, } \\
\text { Ile117, Arg128, Tyr130 }\end{array}$ \\
\hline & Diafenthiuron & -42.02 & 5544 & 663.4 & -13.64 & $\begin{array}{l}\text { Phe17, Ala33, Gly34, Pro39, Ser55, } \\
\text { Lys60, Leu77 }\end{array}$ \\
\hline & Silafluofen & -48.73 & 5920 & 746.5 & -11.65 & $\begin{array}{l}\text { Tyr20, Ile41, Thr54, Ser55, Thr62, } \\
\text { Leu77, Gln98, Ile106, Ile119 }\end{array}$ \\
\hline \multirow[t]{4}{*}{ 4PT1 } & $\begin{array}{l}\text { Control } \\
\text { (Bendiocarb) }\end{array}$ & -33 & 3464 & 437.8 & -10.49 & $\begin{array}{l}\text { Tyr36, Phe47, Leu51, Ile54, } \\
\text { His107, Tyr118, Val121, Val122, } \\
\text { Phe125 }\end{array}$ \\
\hline & Biphenthrin & -47.05 & 5698 & 5698 & -13.24 & $\begin{array}{l}\text { Ile11, Leu51, Ile54, Pro77, His107, } \\
\text { Val121, Val122, }\end{array}$ \\
\hline & Diafenthiuron & -53.85 & 4690 & 696.1 & -19.34 & $\begin{array}{l}\text { Ile11, Tyr50, Leu51, Ile54, Met55, } \\
\text { Asn75, Val76, Pro77, His107, } \\
\text { Tyr110, Tyr118, Val121, Val122, } \\
\text { Phe125 }\end{array}$ \\
\hline & Silafluofen & -35.22 & 5106 & 686.2 & -8.52 & Arg35, Lys111, Pro115, Ser119 \\
\hline \multirow[t]{4}{*}{ 2FLJ } & $\begin{array}{l}\text { Control } \\
\text { (Bendiocarb) }\end{array}$ & -26.08 & 3720 & 461.3 & -6.93 & $\begin{array}{l}\text { Phe17, Tyr20, Met21, Leu77, } \\
\text { Ile106, Ile117, Ile119, Arg128 }\end{array}$ \\
\hline & Biphenthrin & -44.00 & 5862 & 770.3 & -7.36 & $\begin{array}{l}\text { Tyr20, Leu37, Pro39, Lys60, } \\
\text { Leu77, Gln98, Ile106, Ile117, } \\
\text { Arg128 }\end{array}$ \\
\hline & Diafenthiuron & -45.62 & 5974 & 759.2 & -11.68 & $\begin{array}{l}\text { Met21, Val26, Leu53, Phe64, } \\
\text { Leu77, Ile106, Arg108, Arg128, } \\
\text { Tyr130 }\end{array}$ \\
\hline & Silafluofen & -50.41 & 6100 & 846.6 & -12.65 & $\begin{array}{l}\text { Phe17, Tyr20, Lys60, Thr62, } \\
\text { Phe64, Leu77, Ile106, Arg108, } \\
\text { Ile119 }\end{array}$ \\
\hline
\end{tabular}


Table 3: Binding free energy ( $\mathrm{kcal} / \mathrm{mol})$ of the interaction of the selected pesticides with targeted protein

\begin{tabular}{|c|c|c|c|}
\hline \multirow{2}{*}{ Macromolecules } & $\begin{array}{c}\text { Binding free energy } \\
\text { (kcal/mol) }\end{array}$ & Biphenthrin & Diafenthiuron \\
\hline \multirow{2}{*}{2 GVS } & MM/PBSA & -11.48 & -22.36 \\
\cline { 2 - 4 } & MM/GBSA & -14.45 & -26.11 \\
\hline \multirow{2}{*}{$\mathbf{1 F T P}$} & MM/PBSA & -7.16 & -6.70 \\
\cline { 2 - 4 } & MM/GBSA & -16.85 & -14.82 \\
\hline \multirow{2}{*}{ 4PT1 } & MM/PBSA & -27.38 & -24.77 \\
\cline { 2 - 4 } & MM/GBSA & -34.76 & -34.08 \\
\hline \multirow{2}{*}{2 FLJ } & MM/PBSA & -13.00 & -2.85 \\
\cline { 2 - 4 } & MM/GBSA & -27.15 & -39 \\
\hline
\end{tabular}

Table 4: Toxicity pattern analysis of screened top three pesticides

\begin{tabular}{|c|c|c|c|c|}
\hline \multicolumn{5}{|c|}{ Toxicity patterns of top three screened pesticides } \\
\hline Parameters & Biphenthrin & Diafenthiuron & Silafluofen & Remarks \\
\hline AMES toxicity & No & No & Yes & \multirow{9}{*}{ Predicted } \\
\hline $\begin{array}{l}\text { Max. tolerated dose (human) } \\
(\log \mathrm{mg} / \mathrm{kg} / \text { day })\end{array}$ & 0.32 & 0.465 & 0.602 & \\
\hline hERG I inhibitor & No & No & No & \\
\hline $\begin{array}{l}\text { Oral Rat Acute Toxicity }\left(\mathrm{LD}_{50}\right) \\
(\mathrm{mol} / \mathrm{kg})\end{array}$ & 2.776 & 2.432 & 2.433 & \\
\hline $\begin{array}{l}\text { Oral Rat Chronic Toxicity } \\
\text { (LOAEL) (log mg/kg) }\end{array}$ & 0.966 & 1.516 & 1.997 & \\
\hline Hepatotoxicity & No & Yes & Yes & \\
\hline Skin Sensitisation & No & No & No & \\
\hline T. pyriformis toxicity $(\log \mathrm{ug} / \mathrm{L})$ & 0.474 & 0.439 & 0.347 & \\
\hline Minnow toxicity $(\log \mathrm{mM})$ & -2.017 & -1.163 & -3.548 & \\
\hline Bird Toxicity & $\mathrm{No}^{1}$ & $\mathrm{No}^{1}$ & Yes $^{1}$ & {$[21]$} \\
\hline Rat Acute Toxicity $\left(\mathrm{LD}_{50}\right)(\mathrm{mol} / \mathrm{kg})$ & $3.89^{2}$ & $2.269^{2}$ & $\begin{array}{l}\text { No available } \\
\text { Data }\end{array}$ & [44] \\
\hline Fish Toxicity $\left(\mathrm{LC}_{50}\right)(\mathrm{ug} / \mathrm{L})$ & $<100^{3}$ & $\begin{array}{l}\text { No available } \\
\text { Data }\end{array}$ & $\begin{array}{l}\text { No available } \\
\text { Data }\end{array}$ & {$[45]$} \\
\hline
\end{tabular}


Table 5: Prediction of Microbial volatile compound from mVOC

\begin{tabular}{|c|c|c|c|c|c|}
\hline $\begin{array}{c}\text { Pesticide } \\
\text { Name }\end{array}$ & $\begin{array}{c}\text { Microbial Volatile } \\
\text { Compound } \\
\text { structural analog }\end{array}$ & $\begin{array}{c}\text { Structural } \\
\text { Analog } \\
\text { Pubchem } \\
\text { CID }\end{array}$ & Score & Source of Analog & Source \\
Kingdom \\
\cline { 1 - 5 }
\end{tabular}

A)

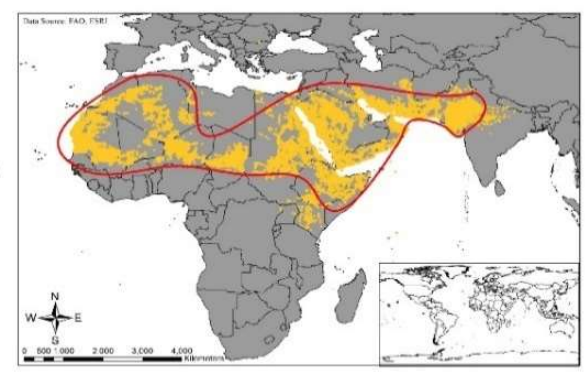

B)

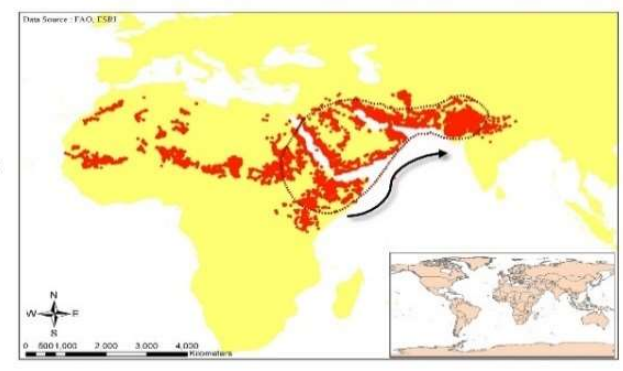

C)

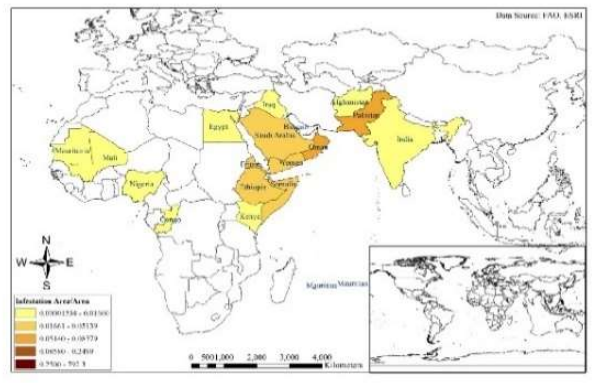


Figure 1. GIS based locust hotspots; A) Desert Locust infestation area over the world from June, 1985 to September, 2020; B) Desert Locust infestation area over the world in 2020; C) Desert Locust infestation severity in 2020 over the world.

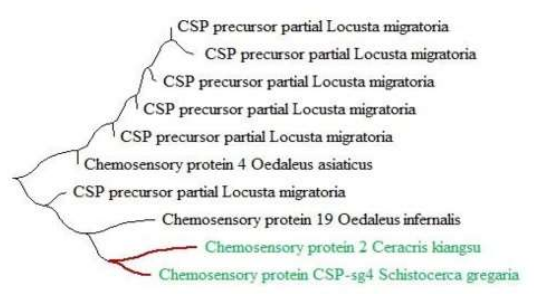

$\stackrel{\longmapsto}{\longmapsto .020}$

A)

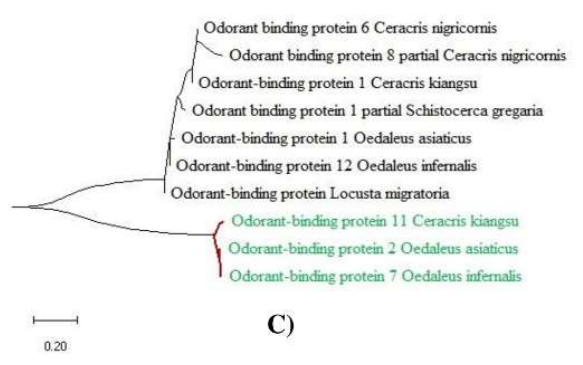

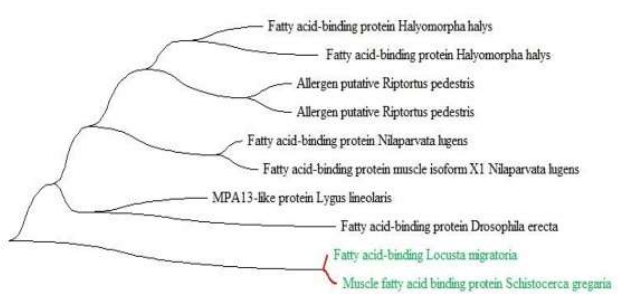

B)

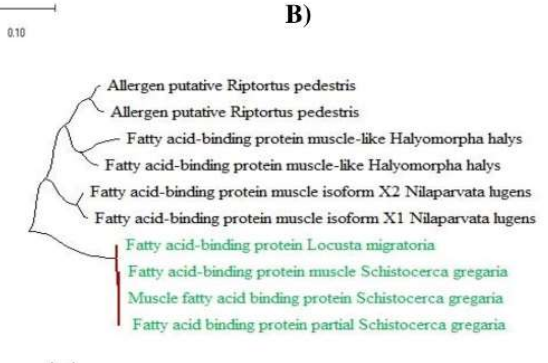

$\stackrel{\text { セ10 }}{\rightleftarrows}$

D)

Figure 2: Phylogenic tree analysis; A) Lipid binding protein of Schistocerca gregaria; B) Muscle fatty acid binding protein of Schistocerca gregaria, C) Odorant binding protein of ocusta igratoria; D) Fatty acid binding protein of Locusta migratoria.

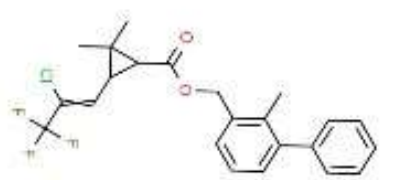

A)<smiles>CCOc1ccc([Si](C)(C)CCCc2ccc(F)c(Oc3ccccc3)c2)cc1</smiles>

B)<smiles>C[N+](=O)NC(=O)NCC1CCOC1</smiles>

Figure 3. Chemical structure of (A)Biphenthrin, (B) Silafluofen and (C) Diafenthiuron. 


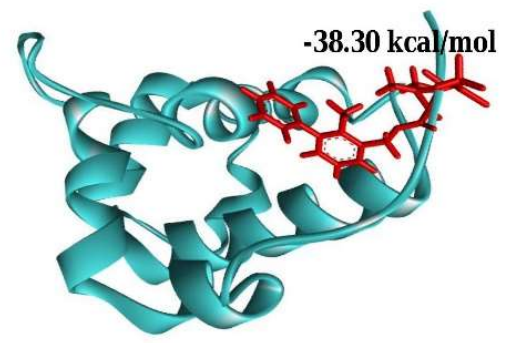

A)

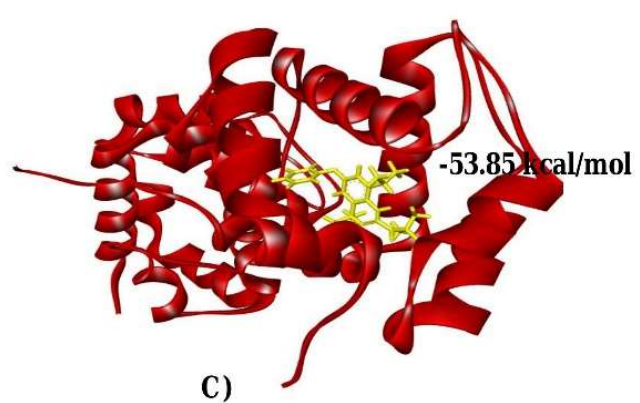

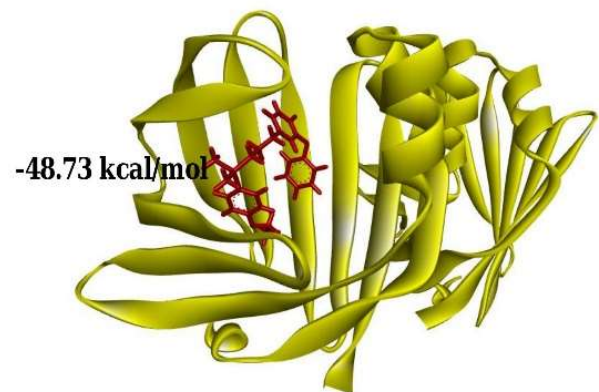

B)

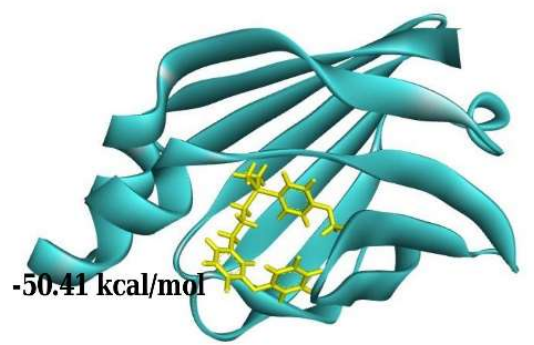

D)

Figure 4: Molecular interaction of A) Biphenthrin with Lipid binding protein of Schistocerca gregaria; B) Silafluofen with Muscle fatty acid binding protein of Schistocerca gregaria, C) Diafenthiuron with Odorant binding protein of Locusta migratoria; D) Silafluofen with Fatty acid binding protein of Locusta migratoria.

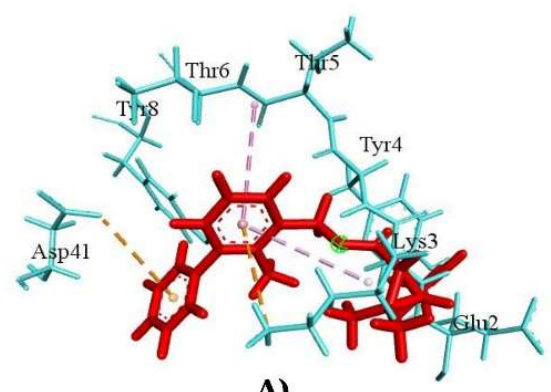

A)

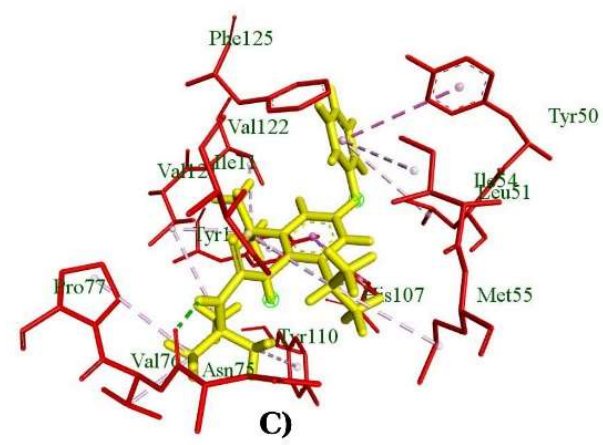

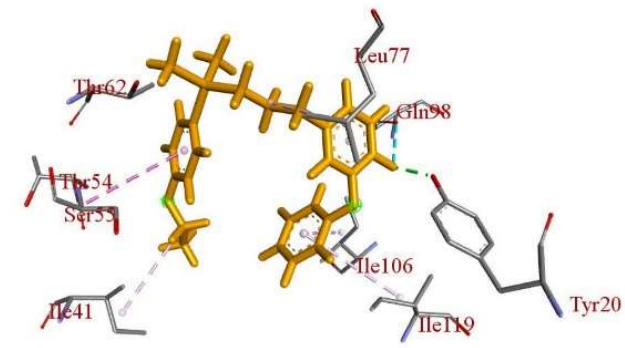

B)

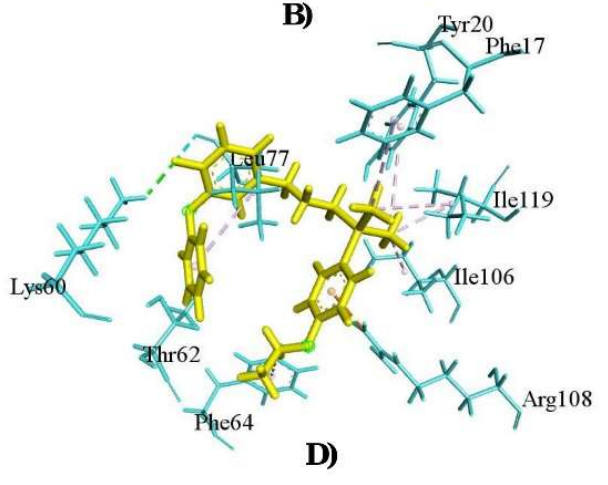


Figure 5: Ligand binding residues of A) Biphenthrin with Lipid binding protein of Schistocerca gregaria; B) Silafluofen with Muscle fatty acid binding protein of Schistocerca gregaria, C) Diafenthiuron with Odorant binding protein of Locusta migratoria; D) Silafluofen with Fatty acid binding protein of Locusta migratoria. 


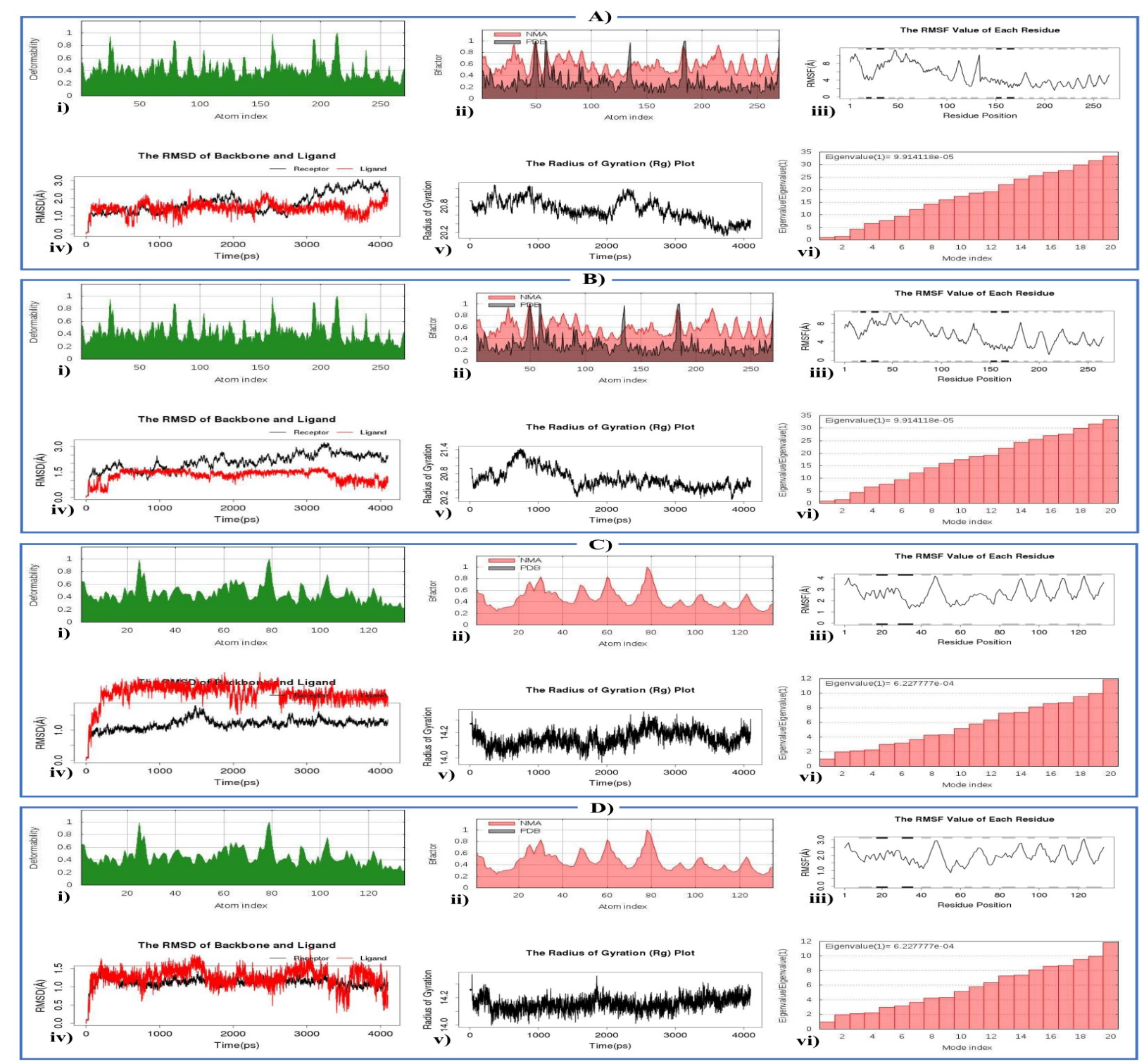

Figure 6: Deformability analysis: A-i) 1FTP with Biphenthrin, B-i) 1FTP with Diafenthiuron, C-i) 2FLJ with Biphenthrin, D-i) 2FLJ with Diafenthiuron; B factor Analysis: A-ii) 1FTP with Biphenthrin, B-ii) 1FTP with Diafenthiuron, C-ii) 2FLJ with Biphenthrin, D-ii) 2FLJ with Diafenthiuron; RMSF plot: A-iii) 1FTP with Biphenthrin, B-iii) 1FTP with Diafenthiuron, C-iii) 2FLJ with Biphenthrin, D-iii) 2FLJ with Diafenthiuron; RMSD plot: A-iv) 1FTP with Biphenthrin, B-iv) 1FTP with Diafenthiuron, C-iv) 2FLJ with Biphenthrin, D-iv) 2FLJ with Diafenthiuron; Rg plot: A-v) 1FTP with Biphenthrin, B-v) 1FTP with Diafenthiuron, C-v) 2FLJ with Biphenthrin, D-v) 2FLJ with Diafenthiuron; Eigen value: A-vi) 1FTP with Biphenthrin, Bvi) 1FTP with Diafenthiuron; C-vi) 2FLJ with Biphenthrin, D-vi) 2FLJ with Diafenthiuron. 


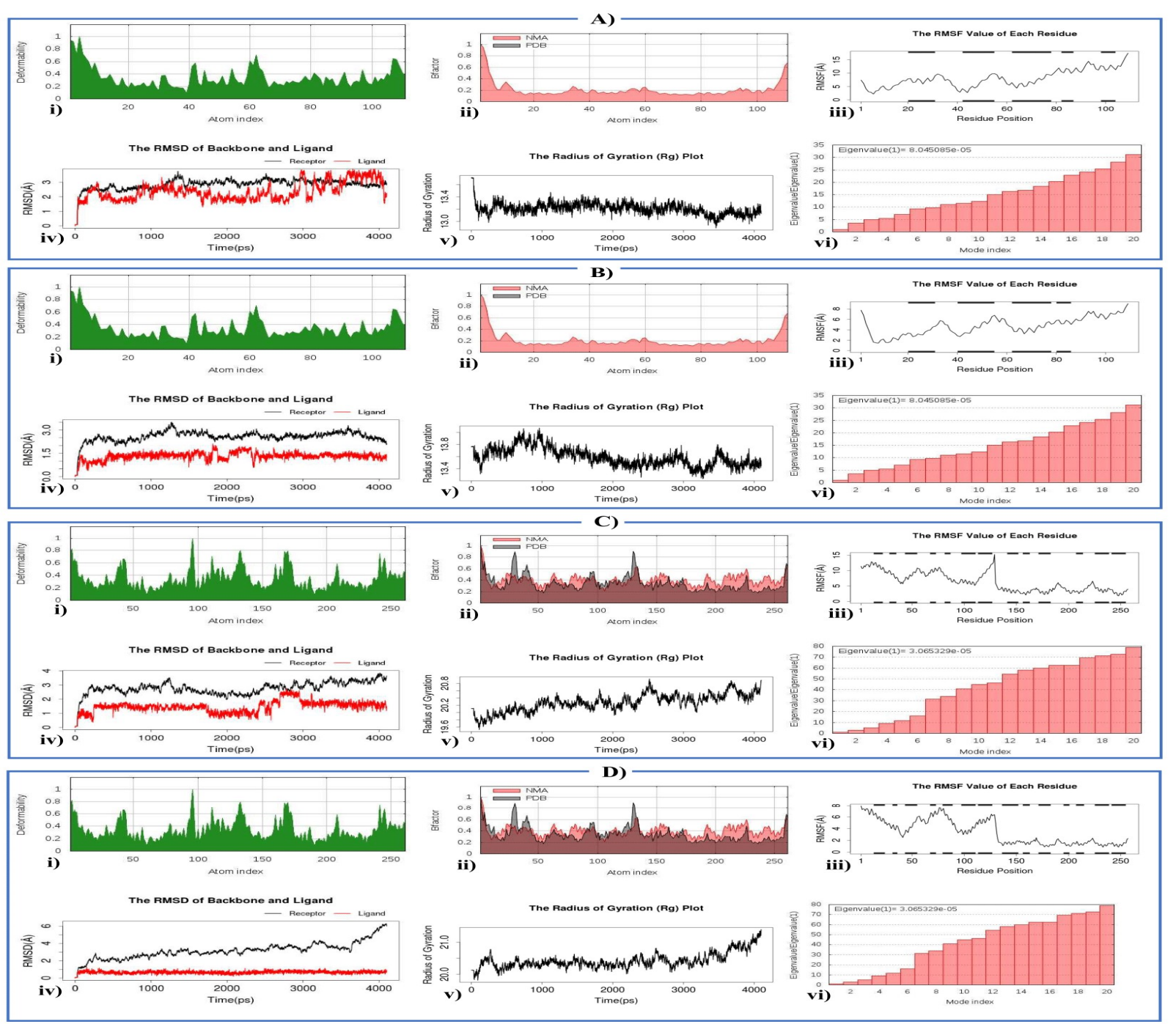

Figure 7: Deformability analysis: A-i) 2GVS with Biphenthrin, B-i) 2GVS with Diafenthiuron, C-i) 4PT1 with Biphenthrin, D-i) 4PT1 with Diafenthiuron; B factor Analysis: A-ii) 2GVS with Biphenthrin, B-ii) 2GVS with Diafenthiuron, C-ii) 4PT1 with Biphenthrin, D-ii) 4PT1 with Diafenthiuron; RMSF plot: A-iii) 2GVS with Biphenthrin, B-iii) 2GVS with Diafenthiuron, Ciii) 4PT1 with Biphenthrin, D-iii) 4PT1 with Diafenthiuron; RMSD plot: A-iv) 2GVS with Biphenthrin, B-iv) 2GVS with Diafenthiuron, C-iv) 4PT1 with Biphenthrin, D-iv) 4PT1 with Diafenthiuron; Rg plot: A-v) 2GVS with Biphenthrin, B-v) 2GVS with Diafenthiuron, C-v) 4PT1 with Biphenthrin, D-v) 4PT1 with Diafenthiuron; Eigen value: A-vi) 2GVS with Biphenthrin, Bvi) 2GVS with Diafenthiuron; C-vi) 4PT1 with Biphenthrin, D-vi) 4PT1 with Diafenthiuron. 